IZA DP No. 5455

An Essay on Real Wage Index Numbers

John Pencavel

January 2011 


\title{
An Essay on Real Wage Index Numbers
}

\author{
John Pencavel \\ Stanford University \\ and IZA
}

\section{Discussion Paper No. 5455 \\ January 2011}

IZA
P.O. Box 7240
53072 Bonn
Germany

Phone: +49-228-3894-0

Fax: +49-228-3894-180

E-mail: iza@iza.org

\begin{abstract}
Any opinions expressed here are those of the author(s) and not those of IZA. Research published in this series may include views on policy, but the institute itself takes no institutional policy positions.

The Institute for the Study of Labor (IZA) in Bonn is a local and virtual international research center and a place of communication between science, politics and business. IZA is an independent nonprofit organization supported by Deutsche Post Foundation. The center is associated with the University of Bonn and offers a stimulating research environment through its international network, workshops and conferences, data service, project support, research visits and doctoral program. IZA engages in (i) original and internationally competitive research in all fields of labor economics, (ii) development of policy concepts, and (iii) dissemination of research results and concepts to the interested public.
\end{abstract}

IZA Discussion Papers often represent preliminary work and are circulated to encourage discussion. Citation of such a paper should account for its provisional character. A revised version may be available directly from the author. 
IZA Discussion Paper No. 5455

January 2011

\section{ABSTRACT}

\section{An Essay on Real Wage Index Numbers}

Real wage index numbers have been used to measure movements in the standard of living of the typical worker. This paper describes some of these indicators for the United States and England. A new real wage index is proposed that resembles the sliding scale used to adjust wages in certain industries years ago. This new index is applied to U.S. manufacturing industry and it suggests a fall in real wages by about 40 percent since 1960. Workers' distributional position in U.S. manufacturing has deteriorated considerably.

\section{NON-TECHNICAL SUMMARY}

This paper provides some history of real wage index numbers in the U.S. and England. Then it proposes a new real wage index number that compares money wages with the most that firms can pay compatible with some base period level of profits. This new wage index indicates that, in U.S. manufacturing, workers have lost ground considerably compared with those whose incomes derive from profits.

JEL Classification: J31

Keywords: index numbers, real wages, sliding scale

Corresponding author:

John Pencavel

Department of Economics

Stanford University

Stanford, CA 94305-6072

USA

E-mail: pencavel@stanford.edu 


\title{
AN ESSAY ON REAL WAGE INDEX NUMBERS
}

\author{
John Pencavel ${ }^{*}$
}

\section{Introduction}

Economists who have worked on constructing a real wage index number have viewed the index as an indicator of the standard of material living of a typical worker. For the motivation behind much of the work on real wage index numbers, it is difficult to improve on Paul Douglas' statement (1930, p. 4) opening his research into the movement of real wages in the U.S. economy a century ago: "There is, indeed, no more important question in the field of social history than that of the 'condition of the people.' [A real wage index] is not only the best index of the relative success and failure of any economic or industrial system, but it also affords the best clue as to the permanency of such a system.......It is therefore highly desirable to chart the economic progress of the largest economic group in our country, namely, those who work for wages or for salaries."1

Notwithstanding this strong statement, Douglas was well aware that the movement of real wages was only an ingredient in measuring changes in standards of living and more information was needed. "[W]hile men and women work as individuals, they generally live within family units and merge their incomes to a greater or lesser degree to meet the common expenses of living.” (Douglas (1930), p. 404) Even when both husband and wife are in the labor force and their incomes are pooled, it provides “......cold comfort for the man who is out of a job to be told that those who are fortunate enough to have jobs have in recent years fared well.” (Douglas (1930), p. 403) For these reasons, Douglas devoted

\footnotetext{
*An abridgment of this paper titled "Real Wage Index Numbers" was presented at the annual meetings of the American Economic Association in Denver in January 2011. In writing this paper, I have received help and advice from George Bulman and Luigi Pistaferri.

${ }^{1}$ A similar motivation lies behind the work of British scholars of real wage index numbers. As noted by Crafts, "The traditional measure of living standards has been an index of real wages" (2007, p. 12). Officer (2009, p. 171) states his intent as that of measuring "the standard of living". This is not to deny the attention that scholars have paid to life expectancy, height, schooling, and other indicators of wellbeing.
} 
considerable effort to augment his series on real hourly earnings with information on the "average annual earnings of the wage-earning class with allowance for unemployment” (pp. 461-91) in which changes in family size, in the number of workers in the household, in unemployment lengths, and in the amount of "free services" affect the evolution of the standard of living of the working class.

Nevertheless, the central element in his research was the creation of a real hourly earnings index formed by dividing a series on money wages or earnings by an index of prices. ${ }^{2}$ Where the goal is to measure changes in the well-being of a typical worker, customarily the price index is a weighted aggregate of the prices of those items that constitute the worker's basket of consumer goods. This price index, sometimes called a cost-of-living index, dates at least from William Fleetwood's (1707) calculation of what the value of a property income flow of $£ 5$ per annum in the period 1440-60 was equivalent to in 1700, prices having risen substantially in the intervening two centuries. ${ }^{3}$ After examining prices over the preceding 600 years paying particular attention to the prices of corn, meat, drink, and cloth, his answer was from $£ 28$ to $£ 30$. Because his four groups of commodities increased at about the same rate, he did not have to confront the question of how his price index ought to treat commodities whose relative prices had changed.

This issue was addressed more than a century later by Joseph Lowe (1822) who examined the course taken by prices during and after the Napoleonic wars. He studied the consumption budgets of

\footnotetext{
${ }^{2}$ Wage rates usually relate to prescribed payments per hour or per day or per task while earnings correspond to actual payments over a period per unit of time worked. In what follows, I shall not distinguish between the two in my narrative but I shall try to be precise in the graphs and tables.

${ }^{3}$ All Souls' founding statutes at Oxford in the mid-fifteenth century called for a Fellow to surrender his appointment if his personal estate exceeded $£ 5$ per year. This became an increasingly disagreeable constraint in a time of rising prices and Bishop Fleetwood was asked whether a Fellow might with conscience retain his college position in an age when the value of money was much lower. On Fleetwood, see Ferger (1946) and Chance (1966). Fleetwood's chronicle of precious money is a fascinating record of English coins including reproductions of silver and gold coins dating from William the Conquerer.
} 
different types of families including those of a “country labourer”, a "town mechanic”, and the “middle classes”. He constructed a quantity weighted price index where the weights were held constant at an initial year.

The early scholars who developed a series on money wages made use of wage or earnings data that had already been averaged by establishment or by industry or by occupation. The weighting scheme to move from these disaggregated values into some representative aggregate was regarded as an issue of first-order importance and the consequence of different weighting procedures was often reported . For instance, Paul Douglas and Albert Rees made extensive use of the U.S. Bureau of Labor Statistics’ (1905) nineteenth annual report, “Wages and Hours of Labor, 1904" which reported results for average hourly wages using four different weighting schemes. ${ }^{4}$

\section{Paul Douglas and Albert Rees}

A century ago, the topic of the movement in real wages in the United States was of major significance with regular articles in the American Economic Review. A common view was that, during the two or three decades before the First World War, real wages rose little and, perhaps, had fallen. ${ }^{5}$

\footnotetext{
${ }^{4}$ Two schemes were to weight by aggregate payrolls or by aggregate employment in each industry as given in the Census of 1900. This implied a weighting scheme that was fixed over time. A third scheme was a simple average of all industries and a fourth was a simple average of all occupations. These two latter schemes imply changing weights. Rees (1960) used changing weights because he wanted to allow for shifts in the industrial and occupational composition of the work force, a procedure that Officer (2009, p. 97) endorses. For his manufacturing series, Douglas used fixed weights based on payroll information for each industry in 1900.
}

${ }^{5}$ Thus, Rubinow (1914, p. 813) reported in 1914 that “.....the sum total of economic progress of this country for the last quarter of a century appears to be a loss of from 10 to 15 per cent in [the American wage-earner's] earning power." Jones (1917, p. 330) amended Rubinow’s price series but came to a similar conclusion: ".....there is nothing in the facts....... which can give the wage-worker cause for rejoicing and that the doctrine so popular in certain quarters that while the rich have grown rapidly richer in recent years the poor have also steadily risen in the scale of economic welfare, has no foundation in fact.” Fairchild (1916, p.24) determined that “......the working families of 1890 enjoyed a higher standard of living than those of 1908" and Douglas and Lamberson (1921) suggested real wages had declined from the 1890s to 1918. Alvin Hansen (1925, p. 40) took it as fact that "In the period from 1897 to 1915 when real wages were falling in spite of an enormous increase in national 
Paul Douglas felt that a comprehensive new research effort was called for and he undertook to create a new earnings series and price series.

He concluded that real earnings did increase between 1890 and 1914 and, in manufacturing, the increase in real average hourly earnings over these years was almost 8 percent. However, compared with the growth in the decades before 1890, this 8 percent increase from 1890 to 1914 implied a retardation in real wage growth. This is evident in Figure 1 that graphs Clarence Long's (1960) real wage series from 1860 to 1890 . The discontinuity is apparent in 1890 when Douglas' series starts. Albert Rees found this slowdown in the growth of real hourly earnings surprising and, for manufacturing industry, he undertook a thorough reexamination of the evidence. ${ }^{6}$ As Douglas had done before him, Rees constructed both a new money wage series and a new price index.

In his series on money wages, Douglas had relied heavily for some of his industries (especially in manufacturing) on union wage scales, a procedure that Rees questioned. Rees argued that union wages tended to be less volatile and somewhat unrepresentative given the extent of unionism at that time. Rees made greater use of the Census of Manufactures and of payroll information collected by (Federal and state) government agencies. Though the level of Rees' money wage series was lower than Douglas', the movement over time of Rees’ money wages and Douglas’ money wages was similar: Rees’ money wage series increased by 55 percent while Douglas’ rose 44 percent. $^{7}$

production, business profits far outran the rise in the general price level.”

${ }^{6}$ Douglas' indexes of real wages were not restricted to manufacturing, but also covered the building trades, coal mining, transport and public utilities, farming, public school teachers, Methodist and Congregational ministers, and some Federal government employees. Rees' critique concentrated on manufacturing as does the account in this paper.

${ }^{7}$ Rees found the similarity in his average hourly earnings manufacturing series and Douglas' money earnings series for "payroll industries" (a group consisting of a subset of all manufacturing industries for which the Bureau of Labor Statistics had undertaken payroll investigations) “astonishing” (p. 37) although the movement in Douglas' all manufacturing series was “rather similar”. For money wages, Douglas constructed a series on full-time weekly earnings whereas Rees compiled a series on daily 
Rees also used different sources (again turning for information to surveys conducted by state agencies) and methods to construct an index of "the prices paid by manufacturing wage earners for consumer goods” (p. 75). For some commodities, Douglas had used wholesale prices whereas Rees made extensive use of price information in the catalogues of Montgomery Ward and Sears Roebuck. In their price series, Douglas had omitted and Rees included estimates of rent for housing. Between 1890 and 1914, Douglas’ cost-of-living index increased by one-third whereas Rees’ increased by onetenth. ${ }^{8}$ This difference in the trend in prices is the principal reason why Rees' series on real wages grows faster than Douglas’.

Putting these differences in wages and prices together, from 1890 to 1914, Douglas’ series on real hourly earnings in manufacturing rose by 8 percent while Rees’ increased by 39 percent. Rees’ series appears more volatile too. Is this difference between Douglas and Rees in the change in real wages over 24 years "large” or "meaningful”? What standard can be used to assess this?

One standard might be to ask whether the latest research on this topic corroborates one or the other? In fact, recent scholarship has yielded a new series of real compensation of production workers in manufacturing industry going back to $1800{ }^{9}$ This has been developed by Lawrence Officer (2009) and it suggests a rise in real hourly compensation between 1890 and 1914 of 36.4 percent, a figure

earnings. This difference was of little moment as Rees treated changes in the length of the full-time work week as changes in daily hours. Both Douglas and Rees wrote that their index described the average for "wage earners” while Long referred to "manual workers".

${ }^{8}$ The expenditure weights in Douglas’ and Rees' cost-of-living index were different and derived from different sources.

${ }^{9}$ This is a series of compensation and, as such, includes wage supplements or benefits. This is an important component of a wage series since the 1930s but less so from 1890 to 1914, as Rees himself observed. Officer's average hourly benefit represents 0 percent of average hourly compensation in 1900 and 0.5 percent in 1914. Officer's price series is also a consumer price index. 
between Douglas' and Rees' but closer to Rees'. ${ }^{10}$ See Figure 2. Officer's price series implies an increase between 1890 and 1914 that is almost identical to Rees’ so Officer's 3 percent lower growth in money earnings accounts for his slightly lower growth in real earnings compared with Rees.

A different standard to assess Douglas’ and Rees’ research is to determine whether a difference of 8 percent and 39 percent over 24 years is something that modern methods and sources would countenance or whether the Douglas-Rees difference reflects the smaller and perhaps less representative samples of past data gatherers. Fortunately, we may draw on some research undertaken by Joseph Meisenheimer (2005) to help answer this. Meisenheimer calculated the increase in real earnings or compensation implied by different contemporary data series from 1979 to 2003, also a 24 year period. The numbers in column (1) of Table 1 are taken from his paper and, using for all the series the CPI as the deflator and depending on the survey, real earnings or compensation rose by as little as 4.6 percent or as much as 32.2 percent in the 24 years between 1979 to 2003.

The numbers in column (2) of Table 1 use a different price deflator, the personal consumption expenditures (PCE) price index and the percent increases in real compensation over these years range from 9.9 percent and 38.9 percent. In other words, the gap between Rees’ 39 percent and Douglas’ 8 percent in real wage increases in the 24 years before the First World War is comparable to the difference between the 39 percent and 5 percent increases in real earnings or compensation in the 24 years from 1979 to 2003, the range of the entries in Table 1. What has been the increase in the real earnings or compensation of workers between 1979 and 2003? According to Table 1, it may have been

\footnotetext{
${ }^{10}$ In his review of Rees’ book, Douglas (1962) argued that Rees’ price series (especially for clothing, home furnishings, and rent) understated the upward drift in prices. Douglas concluded, "If a scholar works in this field thirty years from now with still better methods and sources, he will probably find the truth lies between us.....”. Indeed, 47 years from Douglas' review of Rees' book, Officer did derive a real wage series for 1890-1914 that lies between Douglas’ and Rees’ series.
} 
as little as 4.6 percent or as much as 38.9 percent. $^{11}$

By both standards, Rees’ and Douglas’ series are enduring pieces of scholarship. They compare well with the most recent research of the $1890-1914$ period and the difference between them is not egregious by contemporary measures of changes in real compensation. This comparison of Douglas’ and Rees' estimates of real wage movements over a period of just over two decades illustrates some of the problems posed in forming such a series: which series on money wages should be selected as representative and which series on the price of consumer goods should be used to deflate money wages? These same general issues arise in attempts to construct real wage index numbers not merely over decades but over centuries, to which we now turn.

III. Henry Phelps Brown and Sheila Hopkins and Gregory Clark

In 1955, Phelps Brown and Hopkins (subsequently PBH) published a series on the nominal daily wages of building laborers and craftsmen (especially carpenters and masons) from the thirteenth century to the mid-twentieth century. The sources for these data were principally the financial statements of church records and of Oxford and Cambridge University colleges. PBH describe as "remarkable" the little movement in the wages of craftsmen relative to laborers: the pay of the skilled workers was about 1.5 times that of the unskilled from about the time of the Battle of Agincourt (1415) to the Great War. ${ }^{12}$ PBH describe their somewhat impressionistic methods for handling the

\footnotetext{
${ }^{11}$ The differences among the different series in column (1) of Table 1 are explicable. With the growth in fringe benefits over this period, the increase in compensation (NCS-1) is expected to exceed the growth in earnings (NCS-2). Over a period in which the pay of those in the upper tail of the earnings distribution grew more than the pay of those in the lower tail, the growth in the earnings of lower paid production workers (CES) is expected to fall short of the growth in the earnings of all workers (QC or BEA). The growth in skewness of the earnings distribution helps explain why the growth in mean earnings (NCS-2) exceeds the growth in median earnings (CPS). A case can be made for using any of these series to gauge the growth in a typical worker's pay.

${ }^{12}$ They do not provide much in the way of explanation for this except “.....we cannot believe that market forces always worked to keep the equilibrium prices of the two grades of labour in so constant a relation” (Brown and Hopkins,1955, p. 202).
} 
dispersion of wages for a given occupation in a single year: “ .we avoided any mechanical treatment of the [wage] series for the various crafts and their laborers, but graphed them: then, amid year-to-year movements, we looked for rates which we could regard as representative because they were recurrent” (1955, p. 196). “[T]he question how far they are representative must always be borne in mind” (ibid, p. 201).

In a later paper, $\mathrm{PBH}$ (1956) relate these wage rates to the "prices of some of the main articles of consumption”. They deny they are constructing a measure of real wages "in the modern sense” partly because their price series has some important omissions such as housing costs - though Paul Douglas had also omitted housing rents in the U.S. cost-of-living series referred to above. From fragmentary household expenditure information, $\mathrm{PBH}$ calculate expenditure shares for food and its components and for fuel and light and for textiles, the commodities that figure in their basket of goods. Using the same sources as their wage data supplemented by information about the cost of provisioning the Navy, they form a fixed-weight price series of “consumables” from the mid-thirteenth to the midtwentieth centuries. Abstracting from year to year movements that are partly attributable to the vagaries of the harvest, their price series is trendless for long periods (especially from 1380 to 1510 and, again, from 1630 to 1730). The lack of trend is interrupted with a strong "Tudor inflation" in the sixteenth century and World War-related inflation in the twentieth century.

Notwithstanding their cautionary statement about forming a series on real wages, $\mathrm{PBH}$ divide their real wage series for craftsmen by the price index of a basket of consumables. This noisy real wage series drifts upwards from the mid-fourteenth century to the first decade of the sixteenth century at which time it falls for over a century. Over the seven centuries, they note that their real wage series reaches its lowest point during Shakespeare's time. The trend of real wages from 1800 onwards is strong and positive: real wages in 1954 are more than five times their level in 1800.

Phelps Brown and Hopkins’ work has been visited by Gregory Clark (2005) who has undertaken 
a wholesale reassessment of their results. By making use of conventional regression methods, Clark employs the more "mechanical treatment” that PBH proscribe. With 23,524 observations on the wages of craftsmen and almost 12,000 on the wages of laborers since the thirteenth century, Clark fits error components regression models relating wages to a rich characterization of fixed effects for occupation, location, year, and their interactions. The estimated year effects constitute the basis for his money wage time series. The level of his nominal wage series is usually somewhat lower than that of PBH, but there is little systematic movement in the difference. Clark finds the relative wage of carpenters to laborers changed little from 1400 to 1900 thereby replicating PBH’s “remarkable” findings about skill differentials.

Using a wider range of commodities than had PBH, Clark constructs a cost-of-living index again using a regression error components specification that allows for systematic variations by year, characteristics, location, type of purchaser (usually an institution as it was for PBH), and quality. Budget studies of manual workers are used to weight the price series with the weights fixed from 1200 to 1869. From 1870, Feinstein’s (1995) cost of living series is used.

From 1300 to about 1750, Clark’s cost-of-living index is about 43 to 67 percent higher than PBH's. Clark's lower nominal wages and higher cost-of-living implies lower real wages than PBH's series. The movement of Clark's series differs in details from PBH's, but its broad outlines are similar. Annual averages of real wages for each decade for the two series are graphed in Figures 3 and 4 . For both series, the value of real wages in 1860-69 is set to 100. Figure 3 graphs the series from 1200 to 1860 and Figure 4 is from 1860 to the present. ${ }^{13}$ Though there are important differences between PBH

13 The data graphed in Figures 3 and 4 are the ten year averages of the annual figures where, for example, the entry for 1900 means the average of the ten years from 1900 to 1909. In some early years, an observation may be missing for a particular year in which case the decade's value averages over those observations (years) that are not missing. For the years from 1770 to 1882, yet another index number of real wages of manual workers for Britain (not just England) is Feinstein's (1998). This shows a meagre increase from 1770 to the 1840s, but a larger and more sustained increase for the 
and Clark in the movement of their real wage series in the earlier centuries, their more recent movements are closer. Clark's real wages in the 1950s are 142 percent above their level in the 1850s whereas PBH's increase over the same period is 135 percent.

\section{A Sliding Scale Real Wage Index}

Any market exchange can be viewed from the perspective of the seller or from the perspective of the buyer. Because they use a price index of consumer goods to deflate earnings, all the real wage index numbers reported above adopt the seller's (the worker's) perspective in the exchange of labor services. This is apposite given the goal of using a real wage index to trace movements in a typical worker’s command over consumer goods. However, how might a real wage index be designed if it adopted the position of the buyer of labor services?

There has been no lack of theoretical discussion of production cost indices and of the national output deflator by Court and Lewis (1942), Fisher and Shell (1972), Triplett (1983), and others. Yet I know of no wage index that has actually been constructed from these theoretical contributions. What would a real wage index look like if it assumed the firm's (the typical buyer's) perspective and if it were grounded in established economic theory? To take up this question, consider the canonical pricetaking firm that selects its inputs and, via an amenable production function, chooses the level of its output to maximize net revenues or profits. Its activities are embodied in a maximum profit function $\Pi=f(p, w, r, A)$ where $\Pi$ denotes maximum profits given the output price, $p$, the price of labor, $w$, the price of non-labor inputs, $r$, and an indicator for the state of technology, $A .{ }^{14}$ Provided the form of the profit function is sufficiently tractable, it may be solved to express real wages as a function of the other variables:

remaining nineteenth century.

${ }^{14}$ This profit function is non-decreasing in $p$ and non-increasing in $w$ and $r$. It is homogeneous of degree one in all input and output prices and it is a convex function of its arguments. 


$$
w^{S}=p \cdot g\left(\frac{\Pi}{p}, \frac{r}{p}, A\right)
$$

This is the wage rate solution of the maximum profit function and it shows the highest wage the firm can pay that is compatible with profit level $\Pi$ given $p, r$, and $A .{ }^{15}$ According to equation (1), money wages move proportionately with the firm's output prices holding constant real profits, real nonlabor input prices, and the state of production technology. This correspondence between money wages and product prices is what is implied in the sliding scale in which adjustments in money wages are made in accordance with changes in product prices. The parallel with the sliding scale accounts for the $S$ superscript on $w$ in equation (1). The sliding scale was used in several industries (especially mining and iron and steel) in the United States and Britain from the mid-nineteenth century to the 1930s. Equation (1) may be thought of as the formalisation of the sliding scale.

Equation (1)'s wage-price proportionality depends on the $g($. $)$ function that involves profits and nonlabor input prices. In fact, this is how the sliding scale often operated because, in many instances, the conciliators or arbitrators who were used as third parties ${ }^{16}$ to implement the sliding scale mechanism were known to depart from a one-to-one correspondence between product prices and wages

\footnotetext{
${ }^{15}$ Write the maximand of the profit-maximizing price-taking firm as $\Pi=p X(L, K, A)-w L-r K$. Rearrange this objective so that it reads $w=L^{-1} p[X(L, K, A)-(r / p) K-(\Pi / p)]$ where $\Pi$ may be thought of as fixed contractual payments to creditors. Maximize this expression for $w$ with respect to $L$ and $K$ given $p, r$, and $\Pi$. This program is the dual of the conventional firm's problem of selecting inputs to maximize $\Pi$ given $w, p$, and $r$. The resulting maximized wage function of this dual program may be written $w^{S}=p \cdot g[(r / p),(\Pi / p), A]$ which is the wage rate solution of the profit function in the text. It is straightforward to show that the maximized $w$ is homogeneous of degree one in $p, r$, and $\Pi$ and that $\partial w^{S} / \partial p \geq 0, \partial w^{S} / \partial r \leq 0$, and $\partial w^{S} / \partial \Pi \leq 0$.
}

${ }^{16}$ Not always third parties - sometimes the board executing the sliding scale consisted of equal numbers of employer representatives and workers' representatives. 
if other circumstances had changed. ${ }^{17}$ For instance, if non-labor input prices fell and if technical progress permitted the firm to produce more output from given inputs, an arbitrator might be inclined to award higher wages provided the company earned some reference level of real profits. Denote this reference level of real profits by ( $\Pi / p)_{R}$ in which case equation (1) may be used to determine the maximum wages attainable given prices and the state of technology :

$$
w^{S}=p \cdot g\left[\left(\frac{\Pi}{p}\right)_{R}, \frac{r}{p}, A\right]
$$

We use this wage rate solution of the maximum profit function to derive a real wage index from the perspective of the firm. Thus, in a situation indexed by $t$, suppose product prices are $p_{t}$, nonlabor input prices are $r_{t}$, and the state of technology is given by $A_{t}$. Then the maximum wage the firm can pay in $t$ and yet enjoy reference profits $(\Pi / p)_{R}$ is $\left(w^{S}\right)_{t}$ defined as

$$
\left(w^{S}\right)_{t}=p_{t} \cdot g\left[\left(\frac{\Pi}{p}\right)_{R},\left(\frac{r}{p}\right)_{t}, A_{t}\right]
$$

\footnotetext{
${ }^{17}$ Thus, Carr and Taplin (1962, p. 72) note of the British steel industry that , "Obviously a rigid sliding scale relating wages strictly to prices might operate unfairly against one side or the other under differing circumstances. The operation of the Arbitration and Conciliation Board in effect took these other factors into account, helping to adjust the sliding scale by a variable 'premium' to fit changing circumstances.” In discussing sliding scales, Pigou (1905, pp. 96-100) explicitly lists the prices of other inputs, "mechanical improvements", and profits as among the variables that would induce wage fluctuations when product prices were given. In manufacturing industry, Price (1887, p. 65) recognizes the relevance of raw material prices for "complicating” the sliding scale. Schloss $(1898$, p. 71$)$ noted how the employer's "accustomed rate of profit" affected the setting of piece-rates on the sliding scale. For more recent work on the sliding scale, see Hanes (2010) and Treble (1987).
} 
Suppose we compare $\left(w^{S}\right)_{t}$ with actual wages in situation $t, w_{t}:$ if $w_{t}>\left(w^{S}\right)_{t}$, then wages are higher than the wage that is consonant with reference profits and the other right-hand variables in equation (3) and workers have improved their distributional position within the firm; if $w_{t}<\left(w^{S}\right)_{t}$, wages have fallen relative to what the firm could afford without harming its reference profits. This is an assessment of real wages that views the firm as an organization in which, through bargaining, custom and fairness help determine the division of gross returns between management (on behalf of the capital suppliers) and workers in the way that Alfred Marshall envisaged. ${ }^{18}$ Therefore, instead of constructing a real wage series by dividing money earnings by a price index of consumer goods, let us consider forming a real wage series by dividing money earnings, $w_{t}$, by the sliding scale wage, $\left(w^{S}\right)_{t}$.

Define $V(t)=w_{t} /\left(w^{S}\right)_{t}$. The construction of $w_{t} /\left(w^{S}\right)_{t}$ as an indicator of real wages stresses the distribution of income between workers and capital suppliers. ${ }^{19}$ For this purpose, we make some functional form assumptions. Suppose the profit function is $\ln \Pi=a_{0}+a_{1} \ln p+a_{2} \ln w+a_{3} \ln r+$ $a_{4} A$ where homogeneity requires $a_{1}+a_{2}+a_{3}=1$. Also $a_{1} \geq 0, a_{2} \leq 0$, and $a_{3} \leq 0$. A profit function that is linear in the logarithms of the variables is manifestly simple, but at this exploratory stage something transparent is preferred. Such a profit function is implied by a Cobb-Douglas production function. At this stage of inquiry, in keeping with the real wage series constructed by Douglas and Rees above, we shall restrict the application of these sliding-scale wage index numbers

\footnotetext{
${ }^{18}$ Marshall (1920, pp. 520-1) wrote that “......nearly the whole income of a business may be regarded as a .......composite quasi-rent divisible among the different persons in the business by bargaining supplemented by custom and by notion of fairness....... Thus there is de facto some sort of profit-andloss sharing between almost every business and its employees".

19 Therefore, these constant-profit sliding-scale wage index numbers are quite different from the constant-utility index numbers of real wages constructed from the utility function of the consumerworker (Pencavel (1977)).
} 
to U.S. manufacturing industry for which a Cobb-Douglas production function needs no apology. ${ }^{20}$ With this profit function, the sliding scale wage equation (3) takes the form of

$$
\left(w^{S}\right)_{t}=p_{t} e^{b_{0}}\left(\frac{\Pi}{p}\right)_{R}^{b_{1}}\left(\frac{r}{p}\right)_{t}^{b_{2}} e^{b_{3} A_{t}}
$$

where $b_{0}=-a_{0} / a_{2}, b_{1}=\left(a_{2}\right)^{-1}<0, b_{2}=-a_{3}\left(a_{2}\right)^{-1}<0$, and $b_{3}=-a_{4}\left(a_{2}\right)^{-1}>0$. Higher product prices, lower reference profits, lower nonlabor input prices, and technical change each raises the wage level the firm is able to pay. The parameters in the linear-in-the-logarithm profit function are congeries of the parameters of the Cobb-Douglas production function and we use Douglas' consensus estimates of the production function parameters to form $b_{1}$ and $b_{2}$ in equation (4). ${ }^{21}$

There are a number of possible candidates to serve as reference real profits but, at this stage, we use real profits in 1960. Other values for real profits will affect the values of $w^{S}{ }_{t}$ but, provided reference profits remain constant, they will not affect the index number we compute from $w_{t} / w_{t}^{S}$ which measures the changes or differences in real wages relative to the base year. $\Pi$ is pretax manufacturing corporate profits as reported by the BEA, $p$ is the finished goods price index for manufacturing, $w$ is manufacturing compensation per full-time equivalent employee, $r$ is the price index of capital equipment, and $A$ is a linear time trend. Over the period from 1960 to 2008, increases in $p_{t}$ exert a positive influence on $w^{S}{ }_{t}$ as do the falling values of $(r / p)_{t}$ and technical progress. Thus, $w^{S}{ }_{t}$ rises over

\footnotetext{
${ }^{20}$ Evidence for the Cobb-Douglas function in manufacturing is supplied in Douglas (1948) and Griliches (1967), among many others.

${ }^{21}$ If the production function is $X=\Omega L^{\delta} K^{\beta} e^{\gamma t}, a_{1}=(1-\delta-\beta)^{-1}, a_{2}=-\delta(1-\delta-\beta)^{-1}$, $a_{3}=-\beta(1-\delta-\beta)^{-1}$, and $a_{4}=\gamma(1-\delta-\beta)^{-1}$. Douglas' average values for U.S. manufacturing industry were $\delta=0.63$ and $\beta=0.34$ from which we set $a_{1}=33.33, a_{2}=-21$, and $a_{3}=-11.33$. We assume exogenous technical change in manufacturing is 1.5 percent per year so $\gamma=0.015$ and $a_{4}=0.5$.
} 
time. The increases in $w^{S}{ }_{t}$ outstrip the modest rises in $w_{t}$ with the consequence that the index number formed from $w_{t} / w_{t}^{S}=V(t)$ declines from the early 1970s. This is shown by the series labelled $V(t)$ in Figure 5 where the evolution of this new wage series is compared with the conventional real wage index number, $w^{*}$, defined as average hourly compensation in manufacturing industry divided by the personal consumption expenditures deflator. The conventional real wage increases between 1960 and 2008 by 106 percent. The sliding scale wage index, $V(t)$, falls by almost 40 percent.

To what extent does the sliding scale wage index, $V(t)$, diverge from an exact sliding scale where the ratio of hourly compensation, $\mathrm{w}_{\mathrm{t}}$, to output prices $p_{t}$ is constant? The answer is indicated by the dotted line in Figure 6 which has a similar long-term movement to the conventional real wage, $w^{*}$. Between 1960 and 2008, the ratio of hourly compensation in manufacturing to the personal consumption deflator rose 106 percent and the ratio of hourly compensation in manufacturing to the price of manufacturing output rose 114 percent, but the ratio of hourly compensation in manufacturing to the maximum wage $\left(w^{S}\right)_{t}$ fell 38 percent. This shows that the modification of the exact sliding scale provided by the $g($. ) function in equation (3) is empirically important. Though the price of capital equipment rose, it increases at a slower rate than the price of manufacturing output so $r$ / $p$ is lower by 2008 than its value in 1960. A reduction in $r / p$ implies that, at given inputs and output, the firm enjoys higher net receipts that could be distributed to workers in the form of higher earnings. This distribution appears not to have occurred sufficiently and, from the late 1970 s, actual compensation $w_{t}$ is below the level $w^{S}$ the firm could pay without reducing profits below its reference level. Similarly, positive (and neutral) technical change enhances output at given inputs and this also raises the firm's net revenues. Again some of these enhanced resources could be distributed to workers without injuring reference real profits. This has not occurred to the degree that would prevent actual wages from falling below $w_{t}^{S}$. Hence, if per worker compensation in 2008 is only about 60 percent of what manufacturing 
firms could have paid each worker, where has the real income of these firms gone? The answer is to profits, $\Pi / p$. The values of $w^{*}$ imply that the average real compensation of manufacturing workers has more than doubled between 1960 and 2008, but the values of $V(t)$ indicate that manufacturing workers could have done even better if firms had been content with the level of profits they earned in $1960 .^{22}$ Measured by what their earnings commanded in the consumer goods market place, manufacturing workers appear to have done well over the past fifty years. Measured by what they could have earned if profits had been shared more fully with workers, manufacturing workers have not done well at all over this period. Workers' distributional position within manufacturing industry deteriorated between 1960 (and especially 1972) and 2008.

\section{Conclusion}

By how much have real wages changed over the past $\mathrm{x}$ years? This plain question is asking for the information contained in a real wage index number whose base is $\mathrm{x}$ years ago. This essay has reminded us that the appropriate response to this question might take the form of further questions: hourly or weekly or annual earnings? ; for what group of workers? ; the average or the median or some other point in the wage distribution? ; what index should be used to convert money into real wages? Reasonable people - indeed, reasonable economists - will offer different answers and this confirms what economists have known: to gauge the well-being of workers over time, no single indicator suffices.

\footnotetext{
${ }^{22}$ The average annual values of real profits, $(\Pi / p)$, in 2005, 2006, and 2007 are $159 \%$ of their annual values in 1960, 1961, and 1962.
} 


\section{REFERENCES}

Brown, E.Henry Phelps, and Sheila V. Hopkins, “Seven Centuries of Building Wages”, Economica, 22(87), August 1955, 195-206

Brown, E.Henry Phelps, and Sheila V. Hopkins, "Seven Centuries of the Prices of Consumables, Compared with Builders’ Wage Rates”, Economica , 23(92), November 1956, 296-314

Carr, J.C., and W. Taplin, History of the British Steel Industry, Blackwell, Oxford, 1962

Chance, W.A., “A Note on the Origins of Index Numbers”, Review of Economics and Statistics, 48(1),

February 1966, 108-10

Clark, Gregory, “The Condition of the Working Class in England, 1209-2004", Journal of Political Economy, 113(6), December 2005, 1307-40

Court, Louis M. and H. Gregg Lewis,”Production Cost Indices”, Review of Economic Studies, 10(1), Winter 1942-43, pp. 28-42

Crafts, Nicholas, “Living Standards”, in Nicholas Crafts, Ian Gazeley, and Andrew Newell, eds., Work and Pay in Twentieth Century Britain, Oxford Univ. Press, 2007, pp. 11-34

Douglas, Paul H., Real Wages in the United States 1890-1926, Houghton Mifflin, Boston, 1930

Douglas, Paul H., “Are There Laws of Production?”, American Economic Review , 38(1), March 1948, 1-41

Douglas, Paul H., “Review of ‘Real Wages in Manufacturing, 1890-1914" by Albert Rees”, American Historical Review , 67(2) , January 1962, 446-8

Douglas, Paul H., and Frances Lamberson, “The Movement of Real Wages, 1890-1918", American Economic Review, 11(3) , September 1921, 409-26

Fairchild, Henry Pratt, “The Standard of Living - Up or Down?”, American Economic Review , 6(1), March 1916, 9-25 
Feinstein, Charles H., "Changes in Nominal Wages, the cost of living and real wages in the United Kingdom over two centuries, 1780-1990" in Peter Scholliers and Vera Zamagni, ed., Labour’s Reward: Real Wages and Economic Change in $19^{\text {th }}$ - and $20^{\text {th }}$-century Europe, Edward Elgar, Aldershot, 1995, pp.3-36

Feinstein, Charles H., “Pessimism Perpetuated: Real Wages and the Standard of Living in Britain during and after the Industrial Revolution”, Journal of Economic History , 58(3), September1998, 625-58 Ferger, Wirth F., “Historical Note on the Purchasing Power Concept, and Index Numbers”, Journal of the American Statistical Association, 41 (233), March 1946, 53-7

Fisher, Franklin M., and Karl Shell, The Economic Theory of Price Indices, Academic Press, 1972 Fleetwood, Bishop William, Chronicon Preciosum, first edition 1707, new edition, 1745, reprinted by Augustus M. Kelley, New York, 1969

Griliches, Zvi, “Production Functions in Manufacturing: Some Preliminary Results”, in Murray Brown, ed., The Theory and Empirical Analysis of Production, National Bureau of Economic Research, Columbia Univ. Press, 1967, 275-322

Hanes, Christopher, “The Rise and Fall of the Sliding Scale, or Why Wages Are No Longer Indexed to Product Prices”, Explorations in Economic History, 47, 2010, 49-67

Hansen, Alvin H., "Factors Affecting the Trend of Real Wages”, American Economic Review, 15(1), March 1925, 27-42

Jones, F.W., "Real Wages in Recent Years”, American Economic Review, 7(2), June 1917, 319-30 Long, Clarence D., Wages and Earnings in the United States 1860-1890, National Bureau of Economic Research, Princeton University Press, Princeton, 1960

Lowe, Joseph, The Present State of England in Regard to Agriculture, Trade \& Finance, first ed., 1822, second ed. 1823, reprinted by Augustus M. Kelley, New York, 1967 
Marshall, Alfred, Principles of Economics, Macmillan Student Editions, London, $8^{\text {th }}$ edition, 1920 Meisenheimer, Joseph R. III, “Real Compensation, 1979 to 2003: Analysis from Several Data Sources”, Monthly Labor Review, 128(5), May 2005, 3-22

Officer, Lawrence H., Two Centuries of Compensation for U.S. Production Workers in Manufacturing, Palgrave Macmillan, 2009

Pencavel, John H., “Constant-Utility Index Numbers of Real Wages”, American Economic Review 67(2) , March 1977, 91-100

Pigou, A.C., Principles and Methods of Industrial Peace, Macmillan, New York, 1905

Price, L.L.F.R., “Sliding Scales and Other Methods of Wage-Arrangement in 'the North of England””, Journal of the Royal Statistical Society , 50(1), March 1887, 5-85

Rees, Albert, Real Wages in Manufacturing 1890-1914, National Bureau of Economic Research, Princeton University Press, Princeton, 1961

Rubinow, I.M., “The Recent Trend of Real Wages”, American Economic Review, 4(4), December $1914,793-817$

Schloss, David F., Methods of Industrial Remuneration, third ed., Williams \& Norgate, London, 1898 Treble, John G., "Sliding Scales and Conciliation Boards: Risk-Sharing in the Late $19^{\text {th }}$ Century British Coal Industry”, Oxford Economic Papers, 39(4), December 1987, 679-98

Triplett, Jack E., “Concepts of Quality in Input and Output Price Measures: A Resolution of the UserValue Resource-Cost Debate”, in Murray F. Foss, ed,., The U.S. National Income and Product Accounts: Selected Topics, National Bureau of Economic Research, Univ. Of Chicago Press, 1983, pp. 269-311

United States Department of Labor, Bureau of Labor Statistics, "Wages and Hours of Labor, 1904", Nineteenth Annual Report of the United States Commissioner of Labor, Washington, D.C., 1905 


\section{Figure 1}

Real Hourly Earnings in Manufacturing, United States, 1860-1914

Rees’, Douglas', and Long’s Series, 1890=100

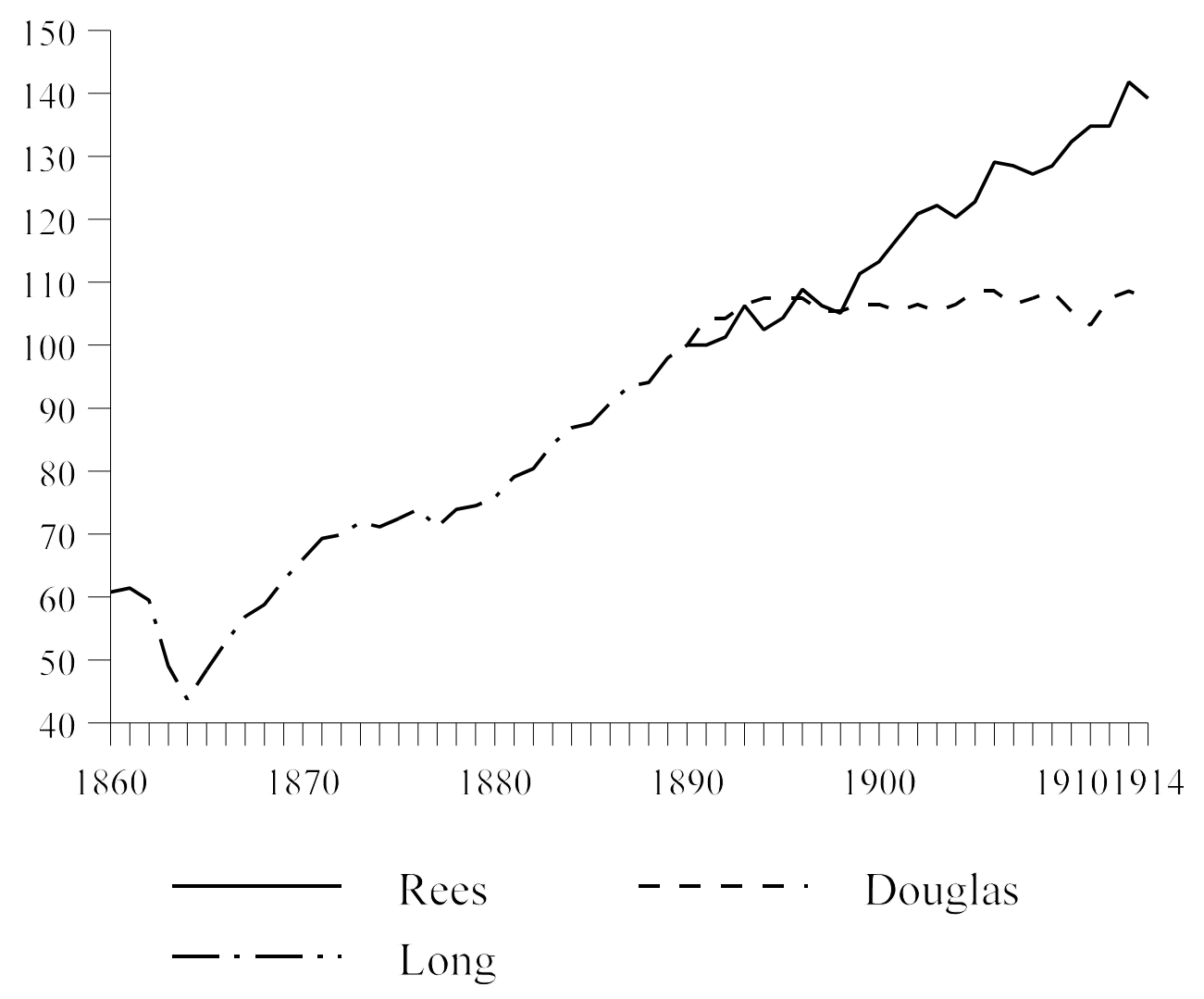

Long's series is taken from Long (1960), Table A-11, p. 153 and converted to an index with 1890=100. Douglas' series is taken from Douglas (1930) Table 24, p 108. Rees' series is taken from Rees (1961), Table 1, page 4 . 
Figure 2

Real Hourly Earnings in Manufacturing, United States, 1890-1914

Rees’, Douglas', and Officer’s Series, 1890=100

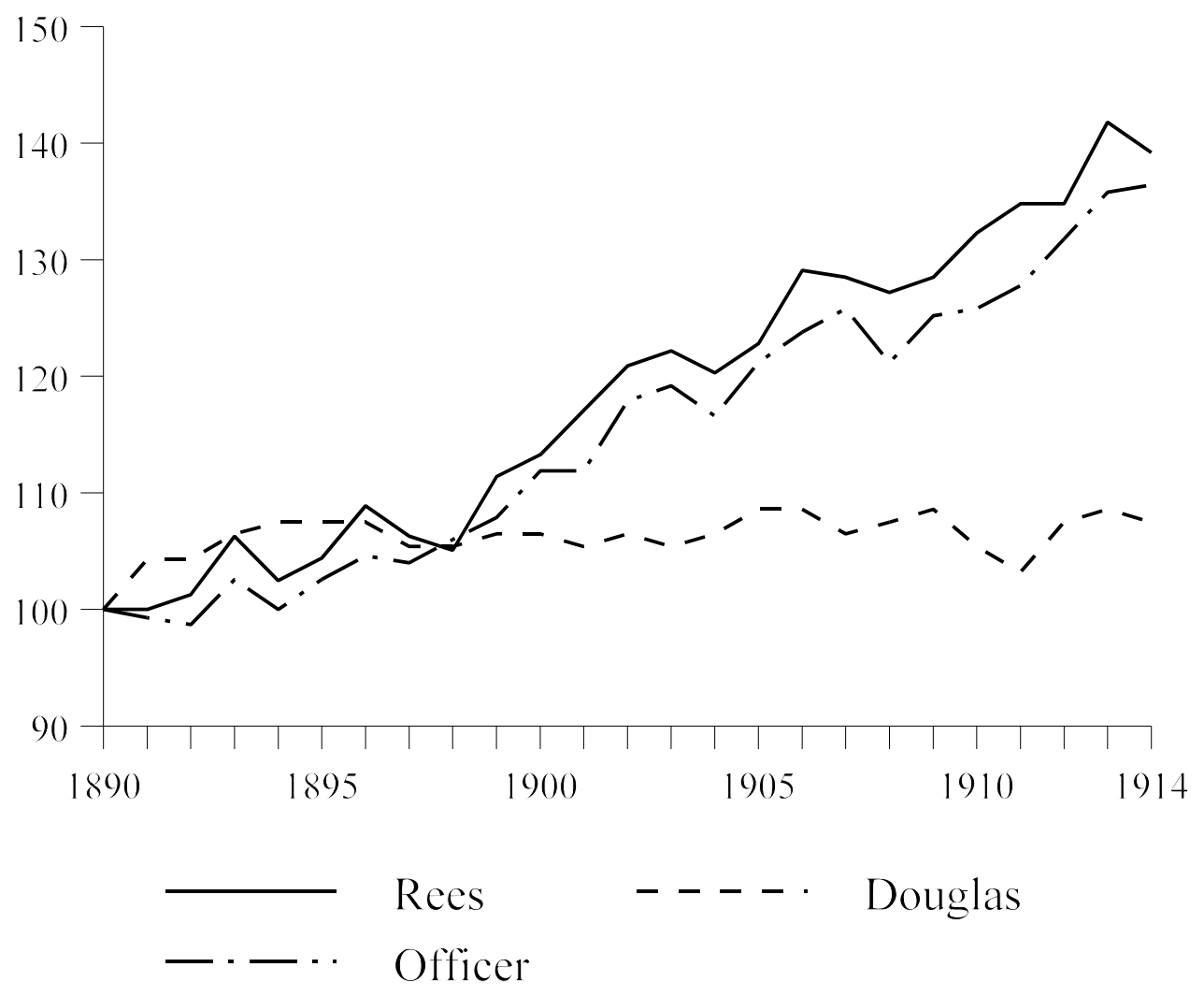

Officer's series is taken from Officer (2009), Table 7-2, p. 170 and converted to an index with $1890=100$. Douglas' series is taken from Douglas (1930) Table 24, p 108. Rees' series is taken from Rees (1961), Table 1, page 4. 
Figure 3

Two Series on the Real Wages of Craftsmen from 1200 to1860 by Decade in England, Phelps Brown and Hopkins from 1260 to 1860 and Clark from 1200 to 1860, 1860$69=100$

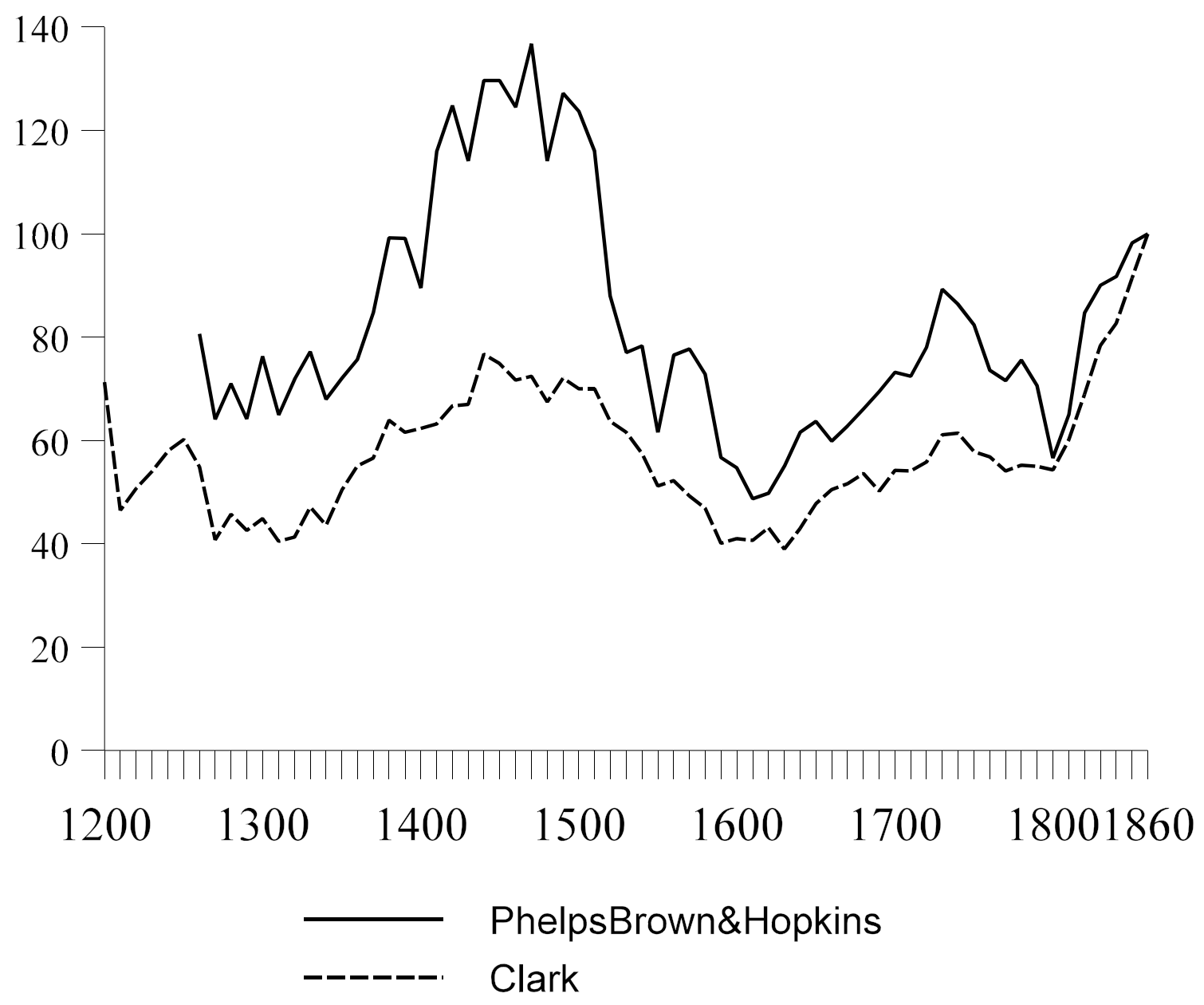

Phelps Brown and Hopkins (1956) is from column (2) of Appendix B. Clark (2005) is from Table A.2, pp. 1324-5. 
Figure 4

Two Series on the Real Wages of Craftsmen from 1860 by Decade in England, Phelps Brown and Hopkins from 1860 to 1950 and Clark from 1860 to 2000, 1860-69=100

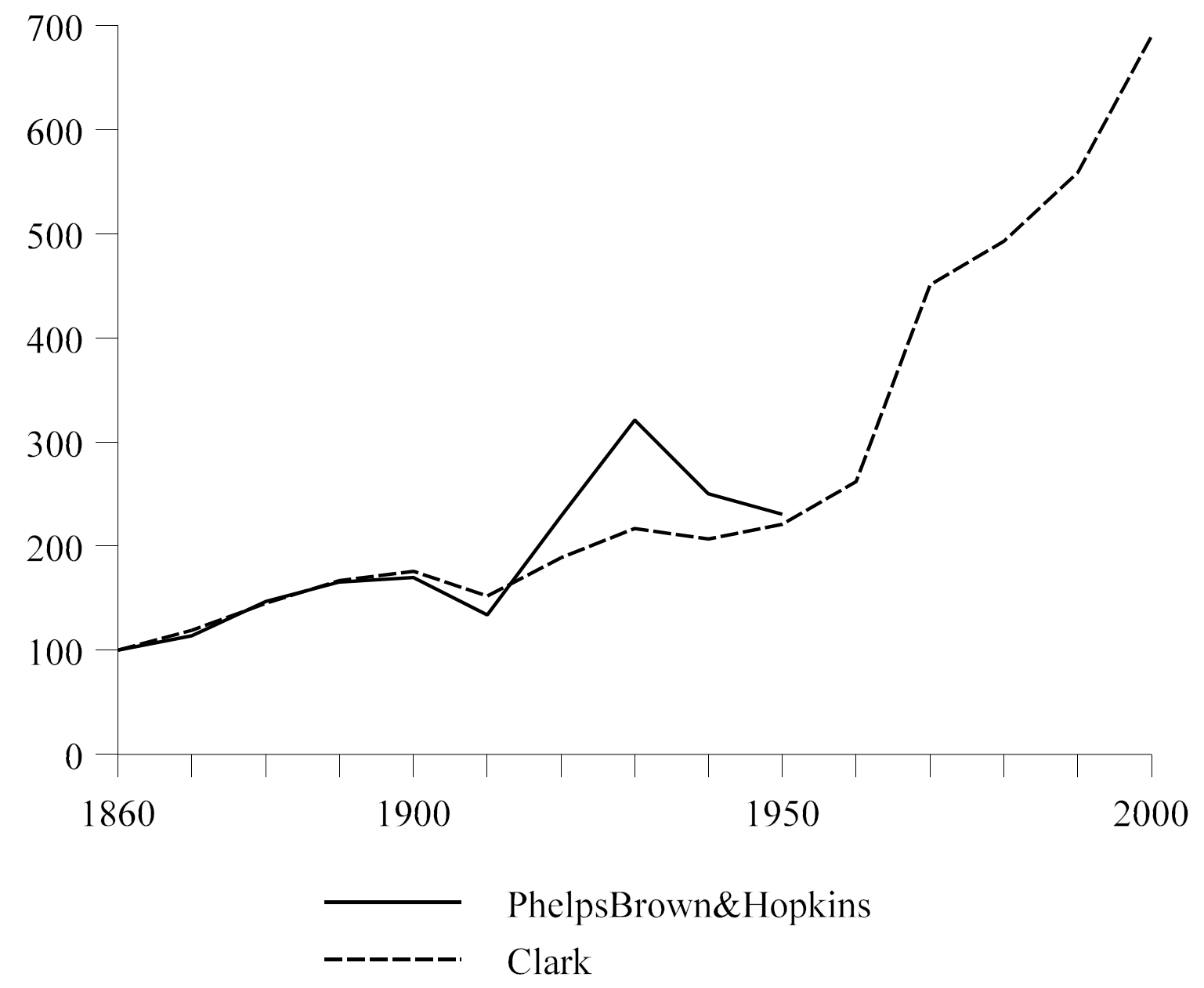

Phelps Brown and Hopkins (1956) is from column (2) of Appendix B. Clark (2005) is from Table A.2, pp. 1324-5. 
Figure 5

Real Compensation Index Numbers in U.S. Manufacturing, $1960=100, w^{*}{ }_{t}$ and $V(t)$

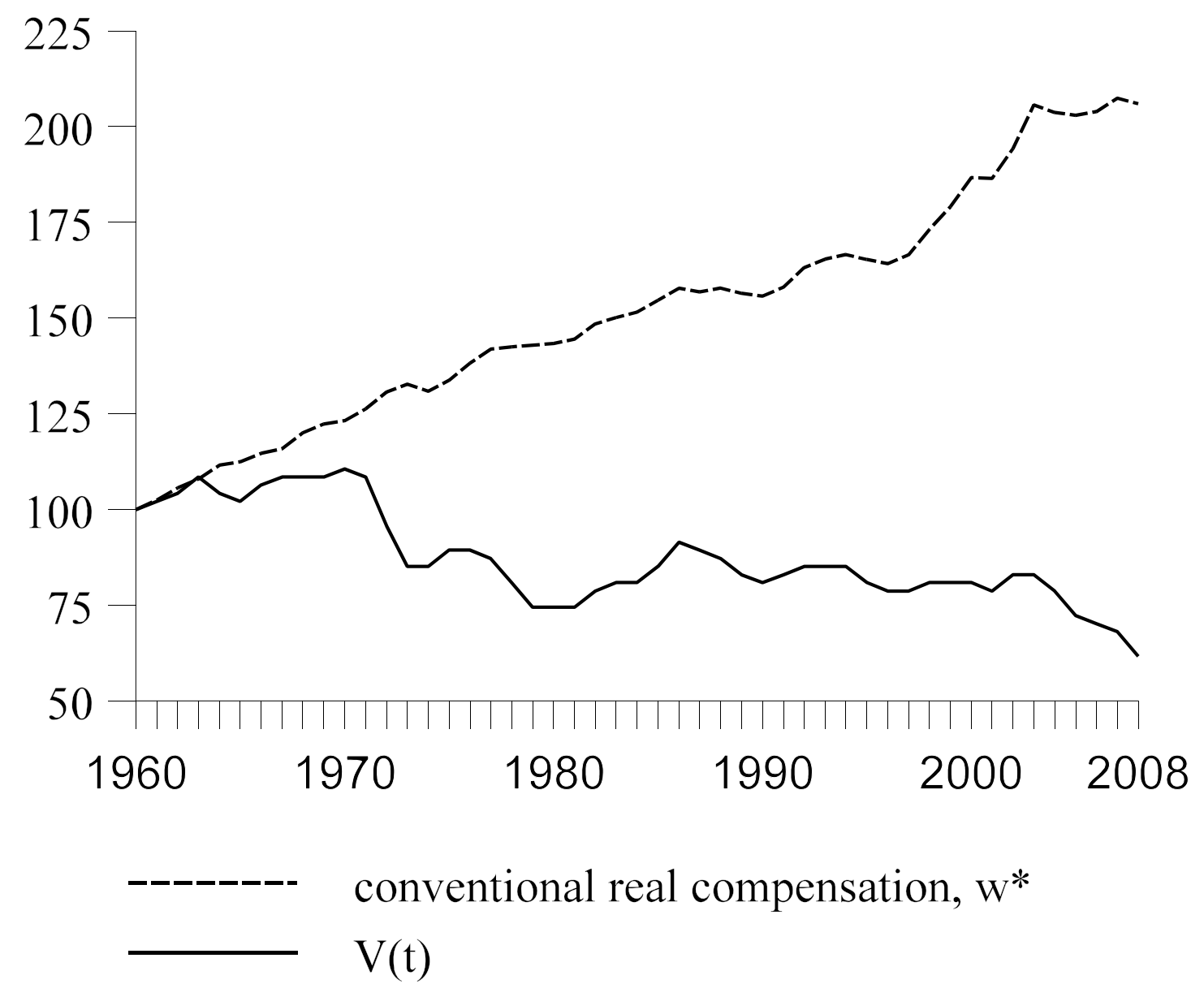


Figure 6

Real Compensation Index Numbers in U.S. Manufacturing, $1960=100$

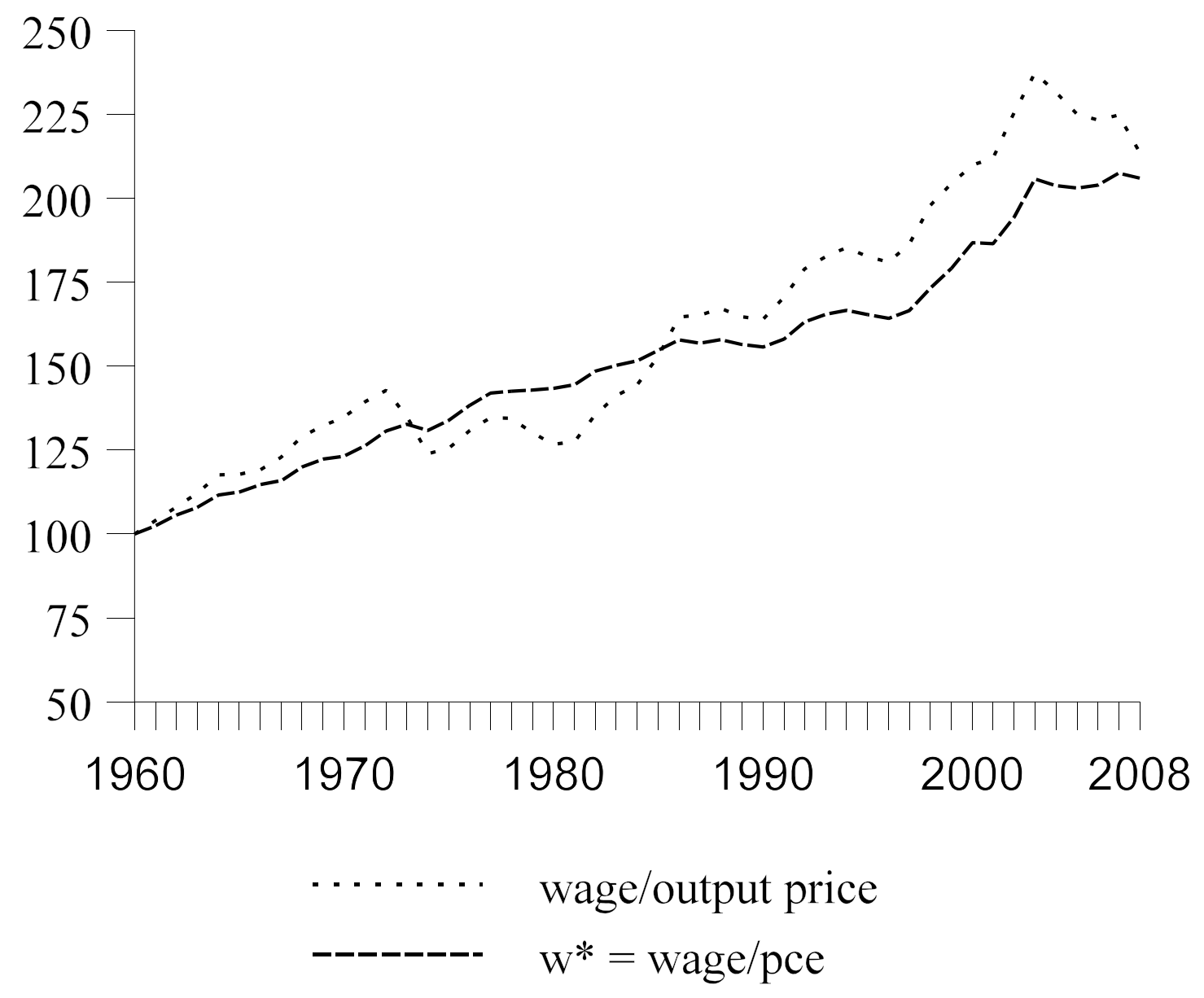




\section{Table 1}

\section{Percent Changes in Real Compensation from 1979 to 2003, Six Different Compensation}

\section{Series and Two Different Price Indices}

\begin{tabular}{|l|c|c|}
\hline & $(1)$ & $(2)$ \\
\hline & with the CPI-U-RS deflator & with the chained PCE deflator \\
\hline NCS -1 & 26.8 & 33.3 \\
\hline NCS-2 & 17.2 & 23.2 \\
\hline CES & 4.6 & 9.9 \\
\hline QC & 22.2 & 28.4 \\
\hline BEA & 32.2 & 38.9 \\
\hline CPS & 10.5 & 16.1 \\
\hline
\end{tabular}

NCS-1 is the percent change in total real compensation per hour worked from the National Compensation Survey (the Employment Cost Index). NCS-2 is the percent change in real wages \& salaries per hour worked from the National Compensation Survey. CES is the percent change in average real hourly earnings of private sector production or non-supervisory workers from the Current Employment Statistics survey. QC is the percent change in annual real wages from the Quarterly Census of Employment and Wages. BEA is the percent change in real hourly compensation in the nonfarm business sector as computed by the BLS using BEA data on total compensation. CPS is the percent change in real median usual weekly earnings of full-time wage and salary workers from the Current population Survey. Column (1) headed CPI-U-RS is taken from Table 3 of Meisenheimer (2005). Column (2) headed PCE deflates each compensation series by the personal consumption expenditures deflator. If 100 is added to each entry in columns (1) and (2), then the resulting entry in column (2) is $\delta$ times the corresponding entry in column (1) where $\delta$ is $\left(P_{03} / P_{79}\right)^{C P I} /\left(P_{03} / P_{79}\right)^{P C E}$. 


\section{Data Appendix to “An Essay on Real Wage Index Numbers”}

column (2) price index of capital equipment (1982=100) from BLS website under Producer Price Index - Commodities.....1959-2009

column (3) corporate profits in billions of nominal dollars in all manufacturing industries in Economic

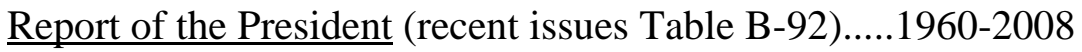

column (4) index of the price of output of manufacturing industries $2000=100, \ldots . .1960-2009$ A price index for total manufacturing output is available from 1986 on the BLS web site under Producer price Index Industry Data: http://data.bls.gov . This was merged with the “all commodities” index for years prior to 1986.

column (5) annual total compensation in nominal dollars per full-time equivalent employee of manufacturing workers, .....1960-2008

column (6) index $(1960=100)$ of manufacturing compensation divided by the price of manufacturing output, $w / p . . . .1960-2008$

column (7) index $(1960=100)$ of manufacturing compensation divided by the consumption expenditures price deflator, $w /$ (pce) ......1960-2008

column (8), index $(1960=100)$ of manufacturing compensation divided by $w^{S}{ }_{t}$ where $w^{S}{ }_{t}$ is formed using the following values of the $b$ coefficients: $b_{1}=-0.0476, b_{2}=-0.5395, b_{3}=0.0238$ .....1960-2008

column (9) index $(1960=100)$ of $w^{S}{ }_{t}$ using Douglas’ production function coefficients, .....1960-2008 column (12) Douglas’ index of real hourly earnings in manufacturing, $1890=100$, final column of Table 24, page 108 of Douglas (1930).....1890-1914

column (13) Rees’ index of real hourly earnings in manufacturing, 1890=100, first column of Table 44, page 120, of Rees (1961).....1890-1914 
column (14) Officer's index of real hourly compensation, 1890=100, Table 7.2, page 170 of Officer (2009).....1890-1914

column (16) Long's index of real hourly wages in manufacturing, 1890=100, Table A-11, page 153 of Long(1960).....1860-90 


\begin{tabular}{|c|c|c|c|c|c|}
\hline (0) & (1) & (2) & (3) & (4) & (5) \\
\hline & year & $\begin{array}{c}\text { price index of } \\
\text { capital } \\
\text { equipment, } r\end{array}$ & $\begin{array}{l}\text { corporate profits } \\
\text { of manuf., } \Pi \text { in } \\
\$ \mathrm{~b}\end{array}$ & $\begin{array}{c}\text { price index of } \\
\text { output, } p\end{array}$ & $\begin{array}{l}\text { BEA per worker } \\
\text { compensation, } w \\
\text { in } \$\end{array}$ \\
\hline & & $1982=100$ & & $2000=100$ & \\
\hline 0 & 1959 & 32.7 & & & \\
\hline 1 & 1960 & 32.8 & 23.8 & 23.3 & 6114 \\
\hline 2 & 1961 & 32.9 & 23.4 & 23.2 & 6317 \\
\hline 3 & 1962 & 33 & 26.3 & 23.3 & 6594 \\
\hline 4 & 1963 & 33.1 & 29.7 & 23.2 & 6822 \\
\hline 5 & 1964 & 33.4 & 32.6 & 23.2 & 7171 \\
\hline 6 & 1965 & 33.8 & 39.8 & 23.8 & 7345 \\
\hline 7 & 1966 & 34.6 & 42.6 & 24.5 & 7667 \\
\hline 8 & 1967 & 35.8 & 39.2 & 24.6 & 7943 \\
\hline 9 & 1968 & 37 & 41.9 & 25.2 & 8538 \\
\hline 10 & 1969 & 38.3 & 37.3 & 26.2 & 9081 \\
\hline 11 & 1970 & 40.1 & 27.5 & 27.1 & 9571 \\
\hline 12 & 1971 & 41.7 & 35.1 & 28.0 & 10228 \\
\hline 13 & 1972 & 42.8 & 42.2 & 29.3 & 10956 \\
\hline 14 & 1973 & 44.2 & 47.2 & 33.1 & 11741 \\
\hline 15 & 1974 & 50.5 & 41.4 & 39.4 & 12793 \\
\hline 16 & 1975 & 58.2 & 55.2 & 43.0 & 14161 \\
\hline 17 & 1976 & 62.1 & 71.4 & 44.9 & 15433 \\
\hline 18 & 1977 & 66.1 & 79.4 & 47.7 & 16828 \\
\hline 19 & 1978 & 71.3 & 90.5 & 51.4 & 18144 \\
\hline 20 & 1979 & 77.5 & 89.8 & 57.9 & 19791 \\
\hline
\end{tabular}




\begin{tabular}{|l|l|l|l|l|l|}
\hline 21 & 1980 & 85.8 & 78.3 & 66.1 & 21973 \\
\hline
\end{tabular}

\begin{tabular}{|l|l|c|c|c|c|}
\hline$(0)$ & $(1)$ & $(2), r$ & $(3), \Pi$ & $(4), p$ & $(5), w$ \\
\hline 22 & 1981 & 94.6 & 91.1 & 72.1 & 24102 \\
\hline 23 & 1982 & 100 & 67.1 & 73.6 & 26147 \\
\hline 24 & 1983 & 102.8 & 76.2 & 74.5 & 27583 \\
\hline 25 & 1984 & 105.2 & 91.8 & 76.3 & 28895 \\
\hline 26 & 1985 & 107.5 & 84.3 & 75.9 & 30485 \\
\hline 27 & 1986 & 109.7 & 57.9 & 73.7 & 31825 \\
\hline 28 & 1987 & 111.7 & 87.5 & 75.6 & 32799 \\
\hline 29 & 1988 & 114.3 & 122.5 & 78.2 & 34321 \\
\hline 30 & 1989 & 118.8 & 112.1 & 82.1 & 35487 \\
\hline 31 & 1990 & 122.9 & 114.4 & 85.8 & 36883 \\
\hline 32 & 1991 & 126.7 & 99.4 & 86.8 & 38826 \\
\hline 33 & 1992 & 129.1 & 100.8 & 87.9 & 41260 \\
\hline 34 & 1993 & 131.4 & 116.8 & 89.2 & 42721 \\
\hline 35 & 1994 & 134.1 & 150.1 & 90.4 & 43956 \\
\hline 36 & 1995 & 136.7 & 176.7 & 93.0 & 44564 \\
\hline 37 & 1996 & 138.3 & 192.0 & 95.2 & 45231 \\
\hline 38 & 1997 & 138.2 & 212.2 & 95.5 & 46711 \\
\hline 39 & 1998 & 137.6 & 173.4 & 94.5 & 49060 \\
\hline 40 & 1999 & 137.6 & 174.6 & 96.1 & 51576 \\
\hline 41 & 2000 & 138.8 & 166.5 & 100.0 & 55082 \\
\hline 42 & 2001 & 139.7 & 57.4 & 100.8 & 56051 \\
\hline 43 & 2002 & 139.1 & 55.1 & 100.1 & 59191 \\
\hline
\end{tabular}




\begin{tabular}{|l|l|c|c|c|c|}
\hline 44 & 2003 & 139.5 & 80.3 & 102.7 & 63939 \\
\hline 45 & 2004 & 141.4 & 178.3 & 107.0 & 65009 \\
\hline
\end{tabular}

\begin{tabular}{|l|l|l|l|l|l|}
\hline$(0)$ & $(1)$ & $(2), r$ & $(3), \Pi$ & $(4), p$ & $(5), w$ \\
\hline 46 & 2005 & 144.6 & 286.05 & 113.0 & 66711 \\
\hline 47 & 2006 & 146.9 & 352.31 & 117.5 & 68840 \\
\hline 48 & 2007 & 149.5 & 322.34 & 122.0 & 71944 \\
\hline 49 & 2008 & 153.8 & 203.13 & 131.7 & 73800 \\
\hline 50 & 2009 & $156.8^{\mathrm{P}}$ & & 125.2 & \\
\hline
\end{tabular}




\begin{tabular}{|c|c|c|c|c|c|}
\hline$(0)$ & (1) & (6) & (7) & (8) & (9) \\
\hline & year & $\begin{array}{l}\text { compensation } \\
\text { divided by } \\
\text { output price, } \\
1960=100\end{array}$ & $\begin{array}{l}\text { compensation } \\
\text { divided by pce } \\
\text { price index } \\
1960=100\end{array}$ & $\begin{array}{l}\text { compensation } \\
\text { divided by } w_{t}^{S} \\
1960=100\end{array}$ & $\begin{array}{l}\text { index of } w_{t}^{S} \\
1960=100\end{array}$ \\
\hline 0 & 1959 & & & & \\
\hline 1 & 1960 & 100 & 100 & 100 & 100 \\
\hline 2 & 1961 & 104.1 & 102.5 & 102.1 & 104.54 \\
\hline 3 & 1962 & 108.1 & 105.7 & 103.6 & 108.42 \\
\hline 4 & 1963 & 112.2 & 108.0 & 105.2 & 113.0 \\
\hline 5 & 1964 & 117.6 & 111.6 & 108.4 & 119.0 \\
\hline 6 & 1965 & 117.8 & 112.5 & 105.5 & 118.64 \\
\hline 7 & 1966 & 119.1 & 114.7 & 103.4 & 119.16 \\
\hline 8 & 1967 & 122.9 & 115.9 & 106.0 & 125.16 \\
\hline 9 & 1968 & 129.1 & 120.1 & 109.4 & 132.06 \\
\hline 10 & 1969 & 132.2 & 122.3 & 109.0 & 134.9 \\
\hline 11 & 1970 & 134.8 & 123.2 & 109.2 & 138.32 \\
\hline 12 & 1971 & 139.4 & 126.3 & 110.6 & 143.59 \\
\hline 13 & 1972 & 142.6 & 130.7 & 109.3 & 145.38 \\
\hline 14 & 1973 & 135.1 & 132.7 & 96.3 & 131.3 \\
\hline 15 & 1974 & 123.9 & 130.9 & 84.6 & 117.88 \\
\hline 16 & 1975 & 125.5 & 133.9 & 86.0 & 122.69 \\
\hline 17 & 1976 & 130.9 & 138.2 & 88.6 & 129.54 \\
\hline 18 & 1977 & 134.7 & 141.9 & 89.1 & 133.45 \\
\hline 19 & 1978 & 134.4 & 142.5 & 86.9 & 133.24 \\
\hline 20 & 1979 & 130.2 & 142.9 & 80.6 & 126.62 \\
\hline 21 & 1980 & 126.7 & 143.4 & 75.4 & 121.19 \\
\hline
\end{tabular}




\begin{tabular}{|c|l|c|c|c|c|}
\hline$(0)$ & $(1)$ & $(6), w / p$ & $(7), w /(p c e)$ & $(8), w / w^{s}{ }_{t}$ & $(9), w^{s}{ }_{t}$ \\
\hline 22 & 1981 & 127.5 & 144.5 & 74.6 & 122.69 \\
\hline 23 & 1982 & 135.5 & 148.5 & 78.8 & 132.89 \\
\hline 24 & 1983 & 141.2 & 150.2 & 80.9 & 139.6 \\
\hline 25 & 1984 & 144.4 & 151.6 & 80.7 & 142.81 \\
\hline 26 & 1985 & 152.9 & 154.7 & 84.7 & 153.33 \\
\hline 27 & 1986 & 164.6 & 157.8 & 91.4 & 169.63 \\
\hline 28 & 1987 & 165.2 & 156.8 & 89.3 & 169.45 \\
\hline 29 & 1988 & 167.2 & 157.9 & 87.7 & 170.54 \\
\hline 30 & 1989 & 164.7 & 156.5 & 83.9 & 167.1 \\
\hline 31 & 1990 & 163.9 & 155.7 & 81.1 & 165.4 \\
\hline 32 & 1991 & 170.5 & 158.1 & 83.2 & 173.77 \\
\hline 33 & 1992 & 178.9 & 163.1 & 85.5 & 182.96 \\
\hline 34 & 1993 & 182.6 & 165.4 & 85.4 & 187.1 \\
\hline 35 & 1994 & 185.3 & 166.7 & 84.9 & 190.48 \\
\hline 36 & 1995 & 182.6 & 165.3 & 81.3 & 186.8 \\
\hline 37 & 1996 & 181.0 & 164.2 & 78.2 & 184.01 \\
\hline 38 & 1997 & 186.4 & 166.5 & 78.5 & 189.15 \\
\hline 39 & 1998 & 197.9 & 173.2 & 81.6 & 201.53 \\
\hline 40 & 1999 & 204.4 & 179.1 & 81.6 & 206.3 \\
\hline 41 & 2000 & 209.9 & 186.7 & 80.5 & 208.24 \\
\hline 42 & 2001 & 212.0 & 186.5 & 79.3 & 210.11 \\
\hline 43 & 2002 & 225.4 & 194.3 & 82.4 & 223.77 \\
\hline 44 & 2003 & 237.3 & 205.7 & 83.7 & 232.71 \\
\hline 45 & 2004 & 231.5 & 203.7 & 78.6 & 223.66 \\
\hline & & & & \\
\hline
\end{tabular}




\begin{tabular}{|c|c|c|c|c|c|}
\hline$(0)$ & $(1)$ & $(6), w / p$ & $(7), w /(p c e)$ & $(8), w / w_{t}{ }_{t}$ & $(9), w_{t}^{s_{t}}$ \\
\hline 46 & 2005 & 225.0 & 203.0 & 73.3 & 213.6 \\
\hline 47 & 2006 & 223.3 & 203.9 & 70.1 & 209.39 \\
\hline 48 & 2007 & 224.7 & 207.5 & 68.2 & 208.43 \\
\hline 49 & 2008 & 213.6 & 206.0 & 61.6 & 193.05 \\
\hline 50 & 2009 & & & & \\
\hline
\end{tabular}




\begin{tabular}{|l|c|c|c|c|c|c|}
\hline$(10)$ & $(11)$ & $(12)$ & $(13)$ & $(14)$ & $(15)$ & $(16)$ \\
\hline & year & Douglas & Rees & Officer & year & Long \\
\hline 0 & 1890 & 100 & 100 & 100 & 1860 & 60.8 \\
\hline 1 & 1891 & 104.3 & 100 & 99.3 & 1861 & 61.4 \\
\hline 2 & 1892 & 104.3 & 101.3 & 98.7 & 1862 & 59.5 \\
\hline 3 & 1893 & 106.5 & 106.3 & 102.6 & 1863 & 49 \\
\hline 4 & 1894 & 107.5 & 102.5 & 100 & 1864 & 43.8 \\
\hline 5 & 1895 & 107.5 & 104.4 & 102.6 & 1865 & 48.4 \\
\hline 6 & 1896 & 107.5 & 108.9 & 104.6 & 1866 & 52.9 \\
\hline 7 & 1897 & 105.4 & 106.3 & 104 & 1867 & 56.9 \\
\hline 8 & 1898 & 105.4 & 105.1 & 106 & 1868 & 58.8 \\
\hline 9 & 1899 & 106.5 & 111.4 & 107.9 & 1869 & 62.7 \\
\hline 10 & 1900 & 106.5 & 113.3 & 111.9 & 1870 & 66 \\
\hline 11 & 1901 & 105.4 & 117.1 & 111.9 & 1871 & 69.3 \\
\hline 12 & 1902 & 106.5 & 120.9 & 117.9 & 1872 & 69.9 \\
\hline 13 & 1903 & 105.4 & 122.2 & 119.2 & 1873 & 71.9 \\
\hline 14 & 1904 & 106.5 & 120.3 & 116.6 & 1874 & 71.2 \\
\hline 15 & 1905 & 108.6 & 122.8 & 121.2 & 1875 & 72.5 \\
\hline 16 & 1906 & 108.6 & 129.1 & 123.8 & 1876 & 73.9 \\
\hline 17 & 1907 & 106.5 & 128.5 & 125.8 & 1877 & 71.2 \\
\hline 18 & 1908 & 107.5 & 127.2 & 121.2 & 1878 & 73.9 \\
\hline 19 & 1909 & 108.6 & 128.5 & 125.2 & 1879 & 74.5 \\
\hline 20 & 1910 & 105.4 & 132.3 & 125.8 & 1880 & 75.8 \\
\hline 21 & 1911 & 103.2 & 134.8 & 127.8 & 1881 & 79.1 \\
\hline
\end{tabular}




\begin{tabular}{|l|c|c|c|c|c|c|}
\hline$(10)$ & $(11)$ & $(12)$ & $(13)$ & $(14)$ & $(15)$ & $(16)$ \\
\hline & year & Douglas & Rees & Officer & year & Long \\
\hline 22 & 1912 & 107.5 & 134.8 & 131.8 & 1882 & 80.4 \\
\hline 23 & 1913 & 108.6 & 141.8 & 135.8 & 1883 & 84.3 \\
\hline 24 & 1914 & 107.5 & 139.2 & 136.4 & 1884 & 86.9 \\
\hline 25 & & & & & 1885 & 87.6 \\
\hline 26 & & & & & 1886 & 90.8 \\
\hline 27 & & & & & 1887 & 93.5 \\
\hline 28 & & & & & 1888 & 94.1 \\
\hline 29 & & & & & 1889 & 98 \\
\hline 30 & & & & & 1890 & 100 \\
\hline
\end{tabular}

